\title{
Different Fire Frequency Impacts Over 27 Years on Vegetation Succession in an Infertile Old-Field Grassland
}

\author{
Wenjin Li, ${ }^{1,3}$ Xiaoan Zuo, ${ }^{2,3}$ and Johannes M. H. Knops ${ }^{4}$
}

\begin{abstract}
Authors are ${ }^{1}$ Assistant Professor, State Key Laboratory of Grassland Agroecosystems, School of Life Sciences, Lanzhou University, Lanzhou, 730000, China; ${ }^{2}$ Associate Professor, Agriculture and Ecology Research Department, Cold and Arid Regions Environmental and Engineering Research Institute, Chinese Academy of Sciences, Lanzhou, 730000, China; and ${ }^{3}$ Visiting Scholar and ${ }^{4}$ Professor, School of Biological Sciences, University of Nebraska, Lincoln, NE 68588, USA.
\end{abstract}

\begin{abstract}
We examined the effect of fire on vegetation composition with the use of an experiment with four different fire frequencies (annual, 2-yr interval, 4-yr interval, and an intended control with no burning) over a 27-yr period in an infertile, old-field grassland at the Cedar Creek Ecosystem Science Reserve, located in Minnesota, United States. We measured the plant species' aboveground biomass in permanent plots in 1983, 1987, 1991, 2000, and 2010. None of these fire frequencies, even after $27 \mathrm{yr}$, had a large impact on the vegetation composition. The plant functional groups' responses to fire frequency were consistent with their respective dominant species. The most abundant $\mathrm{C}_{4}$ grass, little bluestem (Schizachyrium scoparium Michx.), did not change in biomass with fire frequency over time. The biomass of the introduced, invasive grass, Kentucky bluegrass (Poa pratensis L.) decreased significantly with increasing fire frequency, but this decrease did not result in change to the rate and trajectory of vegetation change. Bush clover (Lespedeza capitata Michx.), the only legume in the community, strongly increased with more frequent fire, but only after 20 yr. Species richness and litter mass decreased significantly with increasing fire frequency. These small fire-induced vegetation changes contrast with large fire-induced vegetation changes in fertile grasslands. Management strategies using fire in infertile grasslands can lower Poa abundance; however, increased fire also decreased overall plant diversity.
\end{abstract}

Key Words: $\mathrm{C}_{3}$ and $\mathrm{C}_{4}$ grasses, fire frequency, grassland, legumes, Lespedeza capitata, old field, Poa pratensis, Schizachyrium scoparium, species richness, succession

\section{INTRODUCTION}

Fire is one of the most important ecological factors affecting vegetation communities by eliminating woody species (Briggs et al. 2002; Towne and Kemp 2003) and herbaceous fireintolerant species as well as altering competitive interactions among species. Therefore, fire has long been used to manage grasslands to minimize undesirable plants and increase livestock production (Uys et al. 2004; Pyke et al. 2010).

Most studies examine ecosystem impacts of fire in fertile and mixed tree-grass vegetation systems with high productivity. These studies of more productive ecosystems often show that fire can induce large vegetation shifts and diversity changes (Towne and Kemp 2003; Grace et al. 2007; Pyke et al. 2010). However, vegetation responses to fire in grassland and savanna ecosystems are highly variable and depend on location and ecosystem type. In the North American tallgrass prairie, highfrequency prescribed fires can suppress shrubs and trees and facilitate the establishment and growth of $\mathrm{C}_{4}$ grasses and forbs in fertile and mixed tree-grass vegetation systems (Collins and Steinauer 1998; Reich et al. 2001; Reed et al. 2005; Peterson

Funding for this research was provided by Cedar Creek LTER NSF funding and Natural Science Foundation of China (31100306).

Correspondence: Wenjin Li, State Key Laboratory of Grassland Agroecosystems, School of Life Sciences, Lanzhou University, Huyang Building, 222 Tianshui South Road, Chenguan District, Lanzhou, Gansu, China 730000. Email: liwj@|zu.edu.cn

Manuscript received 16 December 2011; manuscript accepted 5 January 2013.

(c) 2013 The Society for Range Management and Reich 2008). In Texas, USA, repeated fires in any season reduce $\mathrm{C}_{3}$ grass cover and increase $\mathrm{C}_{4}$ grass cover (Ansley et al. 2010). In southern Africa, grasslands have a diverse array of forbs but far fewer grass species, suggesting that forb species tolerate a wider range of season and frequency of fires than the dominant grasses (Uys et al. 2004). In Australia, the effects of frequently applied dormant-season (i.e., winter or early spring) fires shift grassland communities toward $\mathrm{C}_{4}$ grass dominance at the expense of $\mathrm{C}_{3}$ grasses and woody plants (Morgan and Lunt 1999; Prober et al. 2007). In the presence of spring fire, $C_{4}$ grass species outcompete most forbs and $\mathrm{C}_{3}$ grass competitors (Howe 1995), because $\mathrm{C}_{4}$ grass species green up much later in the growing season (Hartnett et al. 1996; Collins and Steinauer 1998). In addition, $\mathrm{C}_{4}$ grasses also have a higher nitrogen and water-use efficiency than $C_{3}$ grasses (Reichman 1987).

In contrast to studies of more productive ecosystems, our 2000 study of $17 \mathrm{yr}$ of different burning frequencies in an infertile grassland in North America revealed only small changes in the vegetation composition and diversity. The 2000 study showed no significant changes in aboveground productivity or in the abundance of the dominant $\mathrm{C}_{4}$ plant species (Knops 2006). Some studies have indicated that fire may change the rate and trajectory of vegetation change by decreasing the abundance of the exotic invader $\mathrm{C}_{3}$ grass, Kentucky bluegrass, which has been increasing in abundance in recent decades (Murphy and Grant 2005; Travnicek et al. 2005; Ansley et al. 2010). This increase could negatively impact ecosystem function, lower plant diversity, and alter seasonal forage distribution (Hendrickson and Lund 2010). 
Therefore, Poa has been identified as a problematic exotic, introduced grass species in US grasslands (Hendrickson and Lund 2010). In a different study at the same site used in the present study, 21 unburned old fields that differed in abandonment age also showed an increase in Poa over time, and the dominant species had a strong influence on the diversity (Miles and Knops, 2009a). Over time, plots dominated by little bluestem had faster rates of compositional change than plots dominated by Kentucky bluegrass (Miles and Knops, 2009b). In our 2000 study, little bluestem dominated the plant biomass across all fire treatments. Kentucky bluegrass was the second most abundant species, increasing over time in the 4-yr-interval fire treatments (Knops 2006).

Studies have often reported that legumes positively respond to increased fire frequency (Ritchie and Tilman 1995) because legume species are positively responding to fire-induced nitrogen losses (Knops et al. 2000) or fire-induced increased cation availability (Ritchie and Tilman 1995). In addition, legumes may be more fire tolerant than nonlegumes (Towne and Knapp 1996). However, legumes are also strongly limited in dispersal because they often have relatively large seeds, susceptible to intense herbivory (Knops et al. 2000). Legumes were absent in this experiment for the first $10 \mathrm{yr}$. However, in the 2000 study we found bush clover, a common prairie legume (Lau et al. 2008) present at very low biomass after 17 yr. If legumes have a competitive advantage in frequently burned grasslands, we would expect a rapid increase in abundance after initial establishment.

For this current study, we examined vegetation changes in a 1983-established experiment with late spring burns applied at four frequencies, namely, annual, 2-yr interval, 4-yr interval, and control (an intended fire exclusion). Vegetation differed in Poa abundance for more than $20 \mathrm{yr}$ (Knops 2006). This study examines changes in the treatment plots over the whole period, including during the last $10 \mathrm{yr}$ (2000-2010). We formulated the following hypotheses: 1) Higher fire-frequency favors increased $\mathrm{C}_{4}$ grass dominance and lowers $\mathrm{C}_{3}$ grass dominance because spring burning increases the competitive advantage of warmseason $\mathrm{C}_{4}$ grasses over the cool-season $\mathrm{C}_{3}$ grasses and forbs that green up earlier in the spring (Hartnett et al. 1996; Collins and Steinauer 1998); 2) higher fire frequency will yield a rapid increase in legume abundance after initial establishment in the frequent burn treatments (Towne and Knapp 1996) because fire can provide a competitive advantage for legumes through increasing cation availability (Ritchie and Tilman 1995); 3) Poa's fire-induced abundance differences among treatments (Schacht and Stubbendieck 1985; Willson and Stubbendieck 1997) will cause changes in species richness and species composition; 4) burning will increase aboveground plant biomass compared with fire suppression (control) because soils in the burned areas will warm up faster in the spring, increasing the length of the growing season (Gartner et al. 1986) and litter removal increases light availability (Amatangelo et al. 2008).

\section{MATERIALS AND METHODS}

\section{Study Area}

This study was set up in an old field, abandoned in 1957 at the Cedar Creek Ecosystem Science Reserve in south-central
Minnesota, United States (lat $45^{\circ} 24^{\prime} \mathrm{N}$, long $93^{\circ} 12^{\prime} \mathrm{W}$ ). Previous cultivation led to the loss of approximately $80 \%$ of the soil organic matter in the top $100 \mathrm{~mm}$ at this experimental site (Knops and Tilman 2000) and nitrogen is the primary mineral nutrient limiting plant productivity (Tilman 1984, 1987). This tallgrass prairie region has a typical midcontinental climate with hot, humid summers, and cold winters. July, the warmest month, averages $28.5^{\circ} \mathrm{C}$ (range 13.9-39.5); January, the coldest month, averages $-5.6^{\circ} \mathrm{C}$ (range -27 to 12.8 ). Snow covers the ground for $4-5$ mo each year. Average rainfall from 1983 to 2000 was $796 \mathrm{~mm}$ and fluctuated from $579 \mathrm{~mm}$ to $1163 \mathrm{~mm}$, but there was no discernible trend over this time period.

Chronosequence studies of abandoned agricultural fields showed that vegetation composition shifted from annual forbs to $C_{3}$ grasses then to $C_{4}$ grasses (Inouye et al. 1987). Little bluestem, Kentucky bluegrass, scribner's panicum (Panicum oligosanthes Schult.), bush clover, rigid goldenrod (Solidago rigida L.), gray goldenrod (Solidago nemoralis Aiton.), sheep sorrel (Rumex acetosella L.), and Pennsylvania sedge (Carex pensylvanica Lam.) are common herbaceous species (Tilman 1987).

\section{Experiment Design}

Plots were established in 1983 and burning started in 1984. Twenty-four plots were randomly placed in a three-by-eight grid with each treatment having six $8 \times 8 \mathrm{~m}$ replicates and $2-\mathrm{m}$ buffers (see Knops 2006 for more details). The four treatments were annual burning, burning every other year (2-yr interval), burning every 4 yr (4-yr interval), and an intended control with no burning (control). Burning by using a strip head fire technique was done each spring in March or April depending on snow melt, with typical air temperatures of $15-25^{\circ} \mathrm{C}$, relative humidity of $25-45 \%$ and winds $<20 \mathrm{~km} \cdot \mathrm{h}^{-1}$ (Reich et al. 2001). Fires generally burned at low intensities, with mean flame lengths $<1 \mathrm{~m}$ (Knops, personal observation). Burning was applied in later spring, either March or April, because $\mathrm{C}_{4}$ grasses stay dormant much longer and might competitively benefit from a lower dominance of $\mathrm{C}_{3}$ grasses and forbs, which are active earlier in the spring (Hartnett et al. 1996; Collins and Steinauer 1998). In 1995, a prescribed fire escaped and burned the entire experiment. In total, the effective fire frequency was thus 27 out of $27 \mathrm{yr}$ for the annually burned plots, 15 out of 27 for the 2 -yr burn interval, 8 out of 27 for the 4 -yr interval, and 1 out of 27 for the control plots.

\section{Sampling Methods}

Vegetation was sampled at the peak of standing biomass in mid-July of 1983, 1987, 1991, 2000, and 2010 by clipping a $0.1 \times 3 \mathrm{~m}$ long strip at ground level in a different area within each plot. All clipped samples were sorted to individual plant species and litter. All plant samples were dried to constant mass at $60^{\circ} \mathrm{C}$. Vascular plants were divided into five functional groups: 1) cool-season $\mathrm{C}_{3}$ grasses; 2) warm-season $\mathrm{C}_{4}$ grasses; 3) herbaceous legumes-comprised solely of the species bush clover; 4) herbaceous forbs; and 5) sedges. No woody species were recorded. Species richness (the total number of species per $3000 \mathrm{~cm}^{2}$ ) and the Shannon diversity index were calculated from species composition data (based on proportional biomass, 

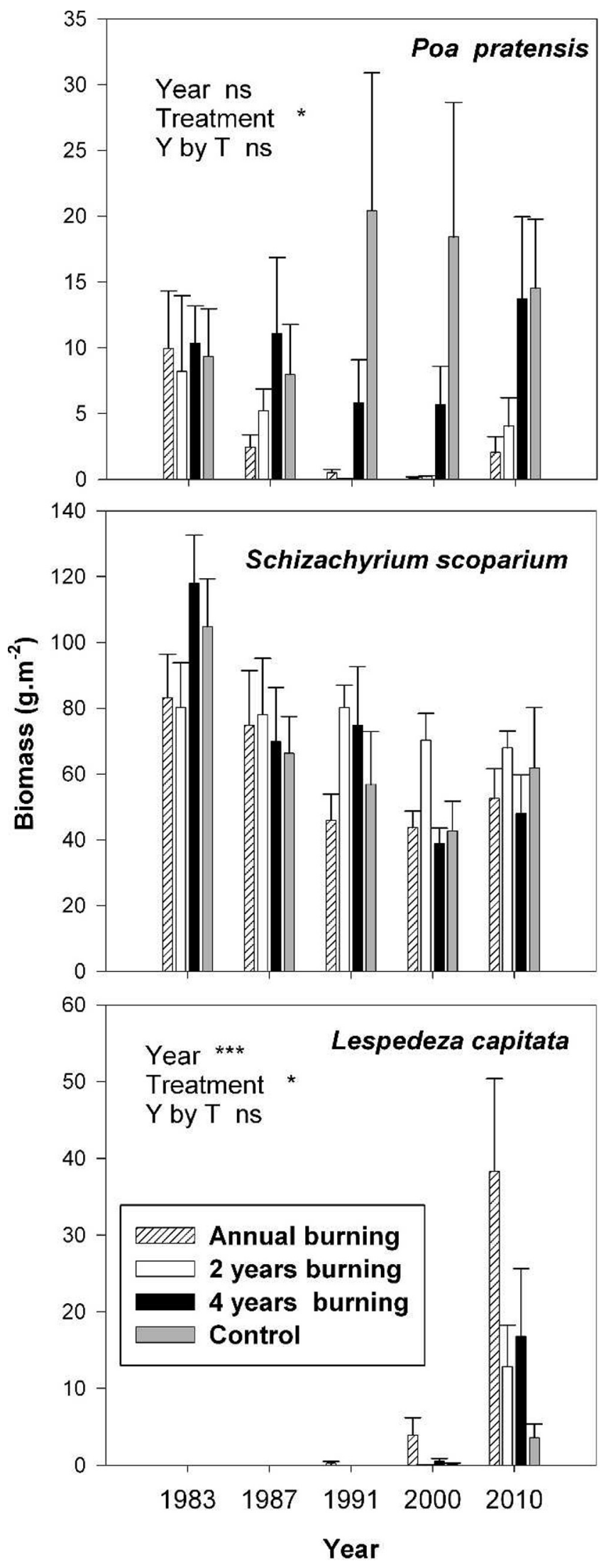

Figure 1. Temporal vegetation changes in the mean $( \pm S E)$ biomass $\left(\mathrm{g} \cdot \mathrm{m}^{-2}\right)$ of the most abundant species biomass under four different burn frequencies over a 27-yr period. Data were analyzed with a repeatedmeasure analysis of covariance (ANCOVA) for year, treatment, and
Magurran 1988). The abundance of each plant functional group was expressed as a proportion of the total standing biomass of each plot. Further details on the vegetation sampling are in Knops (2006).

\section{Statistical Analysis}

Statistical analysis was done with SPSS 18.0. Data was $\ln (x+1)$ transformed when required to improve homogeneity of variances. The temporal effects of burning frequency were analyzed with a repeated-measures analysis of covariance (ANCOVA), with the data from 1983 (the year before the trial commenced) as a covariable, followed by Tukey's post hoc tests to separate means.

\section{RESULTS}

Vegetation biomass ranged from 60 to $140 \mathrm{~g}$ biomass $\cdot \mathrm{m}^{-2}(600$ $\left.1400 \mathrm{~kg} \cdot \mathrm{ha}^{-1}\right)$. At all sampling times, the vegetation was dominated by little bluestem, which contributed $45-90 \%$ of the total aboveground biomass. Other abundant species were big bluestem (Andropogon gerardii Vitman) (0-15\%), Kentucky bluegrass (1-23\%), rough bentgrass (Agrostis scabra Willd.) (0$15 \%)$, quackgrass (Agropyron repens L.) (0-9\%), scribner's panicum (Panicum oligosanthes Schult.) (0-6\%), bush clover (0$35 \%)$; and the forbs common sheep sorrel (Rumex acetosella $\mathrm{L}$.) $(0-10 \%)$ and common yarrow (Achillea millefolium L.) (0-7\%).

\section{Species Composition Changes}

Overall, we found that $27 \mathrm{yr}$ of different burning frequencies had only a minor impact on the vegetation composition. We found no significant change in the most abundant and dominant species, little bluestem, with increasing burning frequency over time $\left(\mathrm{F}_{3,19}=2.32, P=0.108\right)$ (Fig. 1 and Table 1). However, the second most abundant plant species, Kentucky bluegrass, decreased significantly with increasing burning frequency $\left(\mathrm{F}_{3,19}=3.40, P=0.039\right)$, from $10 \mathrm{~g} \cdot \mathrm{m}^{-2}$ of the plant biomass to less than $2 \mathrm{~g} \cdot \mathrm{m}^{-2}$ plant biomass over time, but only in the annual and 2-yr-interval burns (Fig. 1 and Table 1 ), which indicated that the significant treatment effect was consistent over time. Kentucky bluegrass was also the most abundant introduced plant species and the changes in introduced species were largely as a result of a decline in Kentucky bluegrass (Fig. 1 and Tables 1 and 2). The largest impact of fire on the vegetation composition was the rapid increase in the abundance of bush clover in all treatments from 2001 to $2010\left(\mathrm{~F}_{3,19}=3.113, P=0.049\right)$, which was initially absent in all plots (Fig. 1 and Table 1). The first individual bush clover was found after $8 \mathrm{yr}$. It reached $3 \%$ of the plot total biomass after $17 \mathrm{yr}$ and $30 \%$ after $27 \mathrm{yr}$ in the annual burned treatment. In 2000, bush clover was only present in three out of the six annually burned plots. However, in 2010, it developed rapidly and was present in all annually burned plots (Fig. 1).

year $\times$ treatment $(Y \times T)$ interaction effects, with the 1983 year's data as a covariate. ns, not significant: $P \geq 0.05 ;{ }^{\star} P<0.05 ; \quad{ }^{*} P<0.01$; ${ }^{* * *} P<0.001$. See Table 1 for corresponding $F$ values. 
Table 1. $F$ values from a repeated-measure analysis of covariance (ANCOVA) of year, treatment, and year $\times$ treatment interaction on the temporal vegetation changes in the nine most abundant species biomass $\left(\mathrm{g} \cdot \mathrm{m}^{-2}\right)$ under four different burn frequencies: annual, $2 \mathrm{yr}, 4 \mathrm{yr}$, and control.

\begin{tabular}{lcclc}
\hline \multicolumn{1}{c}{ Variances } & Covariable $^{1}$ & Year & Treatment & Year $\times$ treatment \\
\hline Schizachyrium scoparium $^{4} 4.023 \mathrm{~ns}^{2}$ & $1.973 \mathrm{~ns}$ & $2.320 \mathrm{~ns}$ & $1.184 \mathrm{~ns}$ \\
Poa pratensis $^{3}$ & $4.969^{*}$ & $0.792 \mathrm{~ns}$ & $3.396^{*}$ & $1.019 \mathrm{~ns}$ \\
Rumex acetosella & $0.030 \mathrm{~ns}$ & $0.668 \mathrm{~ns}$ & $0.777 \mathrm{~ns}$ & $0.963 \mathrm{~ns}$ \\
Andropogon gerardi & $18.808^{* * *}$ & $1.805 \mathrm{~ns}$ & $0.395 \mathrm{~ns}$ & $0.892 \mathrm{~ns}$ \\
Panicum oligosanthes & $0.016 \mathrm{~ns}$ & $0.598 \mathrm{~ns}$ & $2.340 \mathrm{~ns}$ & $0.866 \mathrm{~ns}$ \\
Agrostis scabra & $0.887 \mathrm{~ns}$ & $0.156 \mathrm{~ns}$ & $0.685 \mathrm{~ns}$ & $0.561 \mathrm{~ns}$ \\
Achillea millefolium & $0.814 \mathrm{~ns}$ & $0.985 \mathrm{~ns}$ & $0.740 \mathrm{~ns}$ & $1.315 \mathrm{~ns}$ \\
Lespedeza capitata & $-{ }^{4}$ & $58.901^{\star * *}$ & $3.113^{*}$ & $2.642 \mathrm{~ns}$ \\
Agropyron repens & $1.357 \mathrm{~ns}$ & $2.696 \mathrm{~ns}$ & $2.836 \mathrm{~ns}$ & $2.909 \mathrm{~ns}$
\end{tabular}

${ }^{1}$ The 1983 biomass data, the year before the fire treatments were applied, were used as a covariable.

${ }^{2}$ ns, not significant: $P \geq 0.05,{ }^{\star} P<0.05,{ }^{*} P<0.01$, and ${ }^{*} * * P<0.001$.

${ }^{3}$ Data were $\ln (x+1)$ transformed to improve homogeneity of variances.

${ }^{4}$ Lespedeza capitata was not present in 1983.

The biomass of all other species was not significantly influenced by fire and successional time (Table 1).

\section{Plant Diversity, Litter, and Plant Biomass Changes}

In total, 66 different plants species have been recorded over the $27 \mathrm{yr}$ of sampling. However, the total number of species recorded in all plots showed no significant difference among the years, varying as follows: 39 species in 1983, 38 species in 1987, 39 in 1991, 37 species in 2000, and 32 species in 2010. Species richness differed significantly among sampling periods $\left(\mathrm{F}_{3,19}=15.85, P=0.001\right)$, and there was a significant fire frequency effect that remained consistent over time, with few species in the more frequently burned treatments $\left(\mathrm{F}_{3,19}=5.97\right.$, $P=0.005$ ) (Fig. 2 and Table 2). However, diversity differed among sampling periods but was unaffected by fire treatment $\left(\mathrm{F}_{3,19}=1.46, P=0.258\right) \quad($ Fig. 2 and Table 2$)$. Although significant differences in total aboveground plant biomass were found among years $\left(\mathrm{F}_{3,19}=7.43, P=0.013\right)$, fire frequency did not change aboveground biomass $\left(F_{3,19}=0.61, P=0.619\right)$, but did not decrease litter mass $\left(\mathrm{F}_{3,19}=10.11, P=0.000\right)$ (Fig. 2 and Table 2).

\section{Plant Functional Group Changes}

$\mathrm{C}_{4}$ grasses accounted for $60-92 \%$ of the total aboveground biomass at each sampling date and were the dominant plant functional group. Fire frequency, however, had no significant impact on the $\mathrm{C}_{4}$ grass abundance $\left(\mathrm{F}_{3,19}=0.74, P=0.539\right)$ (Fig. 3 and Table 2). The variability among plots and treatments was unchanged from 1983, the year before the burning treatment began, to the last sampling session $27 \mathrm{yr}$ later in 2010 (Fig. 3). The most consistent change was a decrease of $\mathrm{C}_{3}$ grass abundance and an increase of legume abundance with increasing fire frequency (Fig. 3). The $\mathrm{C}_{3}$ grass abundance was dominated by Kentucky bluegrass which decreased with increasing fire frequency (Fig. 3). The other subdominant $\mathrm{C}_{3}$ grasses, rough bentgrass, quackgrass and scribner's panicum, did not show a significant response to fire
Table 2. $F$ values from a repeated-measure analysis of covariance (ANCOVA) of year, treatment, and year $\times$ treatment interaction on herbaceous plant species richness (the total number of species per $3000 \mathrm{~cm}^{2}$ ), Shannon diversity index, total plant biomass, litter mass, and the percent plant functional abundance under four different burn frequencies: annual, 2-yr interval, 4-yr interval, and control.

\begin{tabular}{|c|c|c|c|c|}
\hline Variances & Covariable $^{1}$ & Year & Treatment & Year $\times$ treatment \\
\hline Species richness & $1.130 \mathrm{~ns}^{2}$ & $15.845^{\star * *}$ & $5.974^{\star *}$ & $0.953 \mathrm{~ns}$ \\
\hline Shannon diversity index & $0.259 \mathrm{~ns}$ & $8.496 * \star$ & $1.455 \mathrm{~ns}$ & $0.057 \mathrm{~ns}$ \\
\hline Plant biomass & $3.460 \mathrm{~ns}$ & $7.428^{*}$ & $0.607 \mathrm{~ns}$ & $0.275 \mathrm{~ns}$ \\
\hline Litter mass & $2.400 \mathrm{~ns}$ & $1.730 \mathrm{~ns}$ & $10.109 * \star *$ & $7.702^{\star \star \star}$ \\
\hline Percent $\mathrm{C}_{4}$ grasses & $2.238 \mathrm{~ns}$ & $0.483 \mathrm{~ns}$ & $0.743 \mathrm{~ns}$ & $1.545 \mathrm{~ns}$ \\
\hline Percent $\mathrm{C}_{3}$ grasses & $0.066 \mathrm{~ns}$ & $1.314 \mathrm{~ns}$ & $3.426^{*}$ & $0.857 \mathrm{~ns}$ \\
\hline Percent forbs & $0.342 \mathrm{~ns}$ & $2.650 \mathrm{~ns}$ & $2.720 \mathrm{~ns}$ & $0.664 \mathrm{~ns}$ \\
\hline Percent introduced species & $0.000 \mathrm{~ns}$ & $0.100 \mathrm{~ns}$ & $4.051^{*}$ & $1.481 \mathrm{~ns}$ \\
\hline Percent legumes & $0.824 \mathrm{~ns}$ & $15.56^{\star \star \star}$ & $3.541^{*}$ & $3.128^{\star}$ \\
\hline Percent sedges & $16.105^{\star * *}$ & $1.069 *$ & 1.723 ns & $1.078 \mathrm{~ns}$ \\
\hline
\end{tabular}

${ }^{1}$ The 1983 biomass data, the year before the fire treatments were applied, were used as a covariable.

${ }^{2}$ ns, not significant: $P \geq 0.05,{ }^{\star} P<0.05,{ }^{*} * P<0.01$, and ${ }^{*} * * P<0.001$.

and did not change in abundance over time (Table 1). Similarly, bush clover was the only legume present in this experiment (Fig. 3). High fire frequency significantly decreased the abundance of introduced species $\left(\mathrm{F}_{3,19}=0.41, P=0.022\right)$, driven by changes in Kentucky bluegrass, over the $27 \mathrm{yr}$ of treatments (Fig. 3). Sixty percent of the plant diversity within this experiment was made up of forbs; however, fire did not influence the abundance of the forb functional group. The sedge category was made up of wiry flatsedge (Cyperus filiculmis Vahl) and unidentified sedge species (the latter primarily Pennsylvania sedge that did not flower and were only identifiable to the genus level). Most of the sedge species at the study site are clonal, which leads to large variability among plots. Thus even though there is a pattern of increased sedge biomass in the annual burned treatment, this pattern was not significant (Table 2).

\section{DISCUSSION}

Most remarkable about this study is how little influence the different fire treatments had on vegetation composition, even after 27 yr of application. Similarly, as reported in 2000, after 17 yr (Knops 2006) fire had no impact on aboveground productivity, the most abundant $\mathrm{C}_{4}$ plant species, or the Shannon diversity index, but we did find decreased species richness with increased fire frequency. Many studies in North American tallgrass prairie have shown that fire can increase $\mathrm{C}_{4}$ grasses abundance (Collins and Steinauer 1998; Reich et al. 2001; Peterson and Reich 2008). However, standing biomass in our trial was generally low, i.e., 600-1 $400 \mathrm{~kg} \cdot \mathrm{ha}^{-1}$, and with relatively little litter, compared with neotropical savannas with herbaceous biomass ranges from 3500 to $5500 \mathrm{~kg} \cdot \mathrm{ha}^{-1}$ after 1-3 yr since the last fire (Kauffman et al. 1994) and tallgrass prairie with standing biomass of $2500-6500 \mathrm{~kg} \cdot \mathrm{ha}^{-1}$ (Towne and Kemp 2003). Thus, as shown by the lack of any change in the dominance of $\mathrm{C}_{4}$ grasses, and the most abundant $\mathrm{C}_{4}$ grass, little bluestem, fire does not provide a competitive advantage 

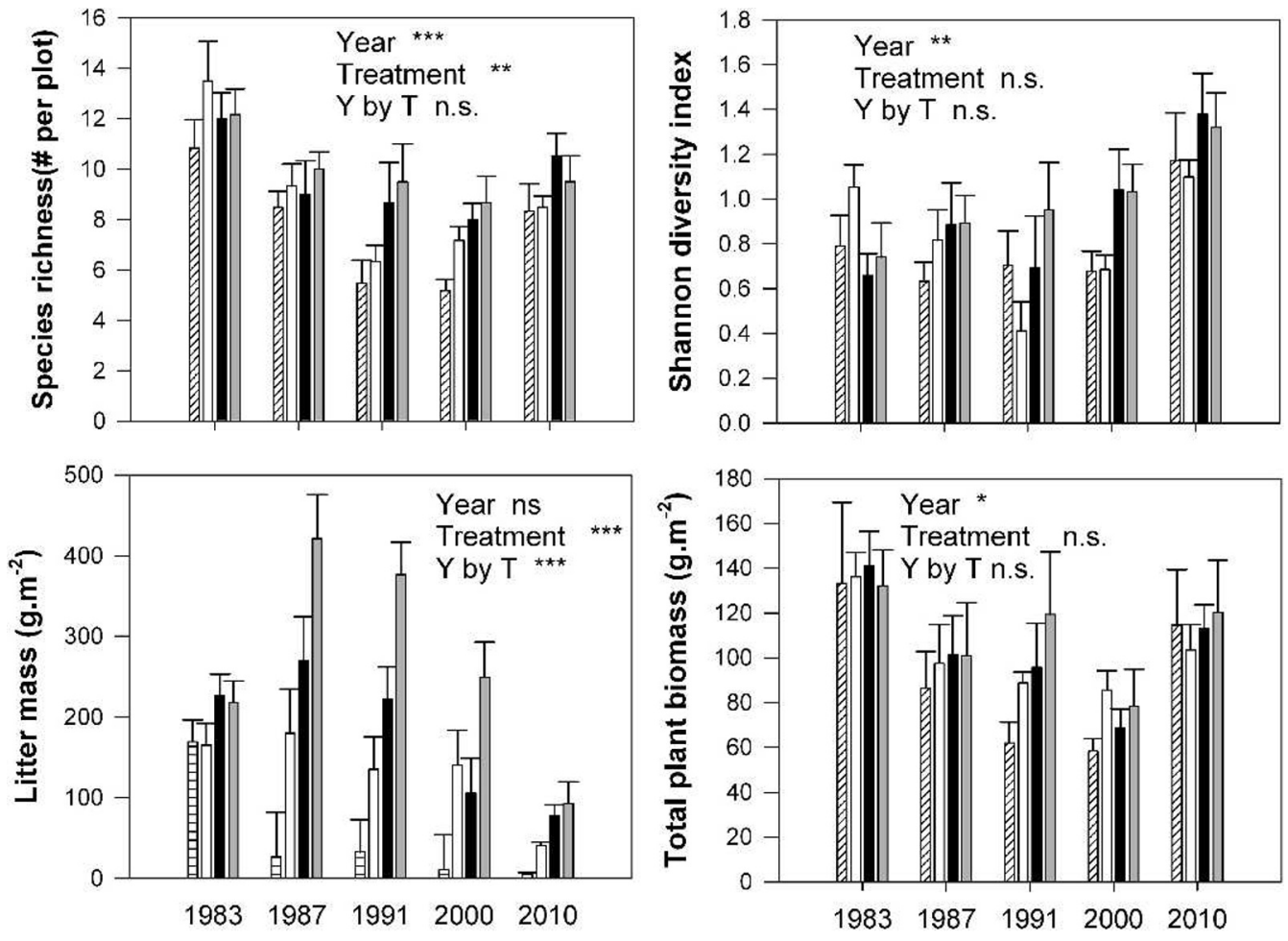

Year

VIIIS Annual burning $\square 2$ years burning 4 years burning $\square$ Control

Figure 2. Temporal vegetation changes in the mean $( \pm S E)$ species richness, Shannon diversity index, total plant biomass, and litter mass under four different burn frequencies over a 27-yr period. Data were analyzed with a repeated-measure analysis of covariance (ANCOVA) for year, treatment, and year $\times$ treatment $(\mathrm{Y} \times \mathrm{T})$ interaction effects, with the 1983 year's data as a covariate. ns: not significant, $P \geq 0.05 ;{ }^{\star} P<0.05$; ${ }^{\star \star} P<0.01$; ${ }^{\star \star \star} P<0.001$. See Table 2 for corresponding $F$ values.

for the $\mathrm{C}_{4}$ grasses in this low productive unfertile grassland. This contrasts with more fertile fields with aboveground net primary productivity (ANPP) that ranged from 2000 to 12000 $\mathrm{kg} \cdot \mathrm{ha}^{-1} \cdot \mathrm{yr}^{-1}$ at the Cedar Creek Natural History Area in eastcentral Minnesota, where fire favors the establishment and growth of $\mathrm{C}_{4}$ grasses (Reich et al. 2001; Peterson and Reich 2008). Thus, fire's impact on prairie productivity and species composition strongly depends on the site's fertility and productivity.

The burning-treatment-induced differences in the abundance of the introduced Kentucky bluegrass, do not appear to have mediated any other changes in the vegetation. Frequent burning reduced the abundance of Kentucky bluegrass, but species richness also declined with increasing fire frequency. Fire decreased the abundance of some of the rare species but did not significantly change the abundance of the more common ones, and management strategies aimed at increasing grassland diversity that try to lower Poa abundance by increased burning may be counterproductive, at least in infertile grasslands.

The only major change in the vegetation over the last $10 \mathrm{yr}$ was the increased abundance of bush clover, which now comprises $30 \%$ of the biomass in the annually burned treatment. Fertilization studies within the same field have shown that nitrogen is the main factor that determines the outcome of plant competition, and that nitrogen limits net primary productivity (Tilman 1984, 1987). Legumes are often good invaders in nitrogen-limited ecosystems (Tilman, 1997; Li et al. 2010), and it has been hypothesized that fire can reduce $\mathrm{N}$ and increase cation availability, which can lead to a competitive advantage for legumes (Ritchie and Tilman 1995). In the last $10 \mathrm{yr}$, we have found a significant increase in bush clover, but no differences yet in nitrogen pools or fluxes (J. M. H. Knops, unpublished data). At the same site, in 22 unburned old fields ranging in abandonment age from 1 to 56 yr, legume cover did not exceed $6 \%$ in any field, and was not significantly correlated with field age (Inouye et al. 1987). Thus, compared with natural recovery, regular burning could favor the establishment of bush clover. This increase in its abundance has the potential to lead to increased nitrogen with inputs, which ultimately may lead to vegetation changes (Knops et al. 2000; Lau et al. 2008). Therefore, it will likely take decades for fire to alter the native composition of infertile grasslands significantly.

\section{MANAGEMENT IMPLICATIONS}

Fire-induced vegetation changes differ among grasslands that differ in productivity. In contrast to fertile grasslands, fire does not significantly impact vegetation composition in this infertile prairie. Fire does, however, significantly decrease the abun- 

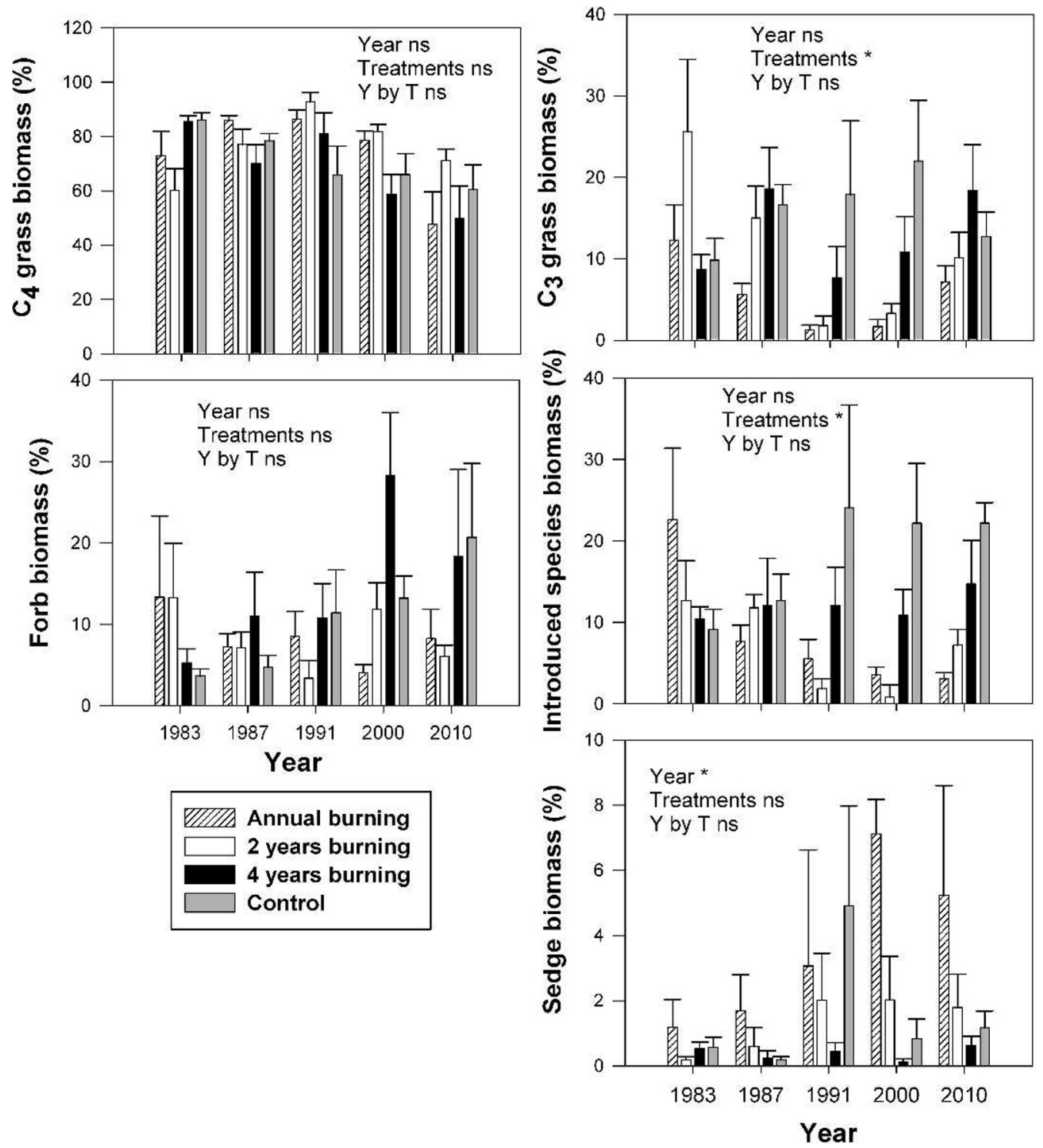

Figure 3. Temporal vegetation changes in the mean ( \pm SE) percentage biomass of functional groups in response to four different burning frequencies over a 27-yr period. Data were analyzed with a repeated-measure analysis of covariance (ANCOVA) for year, treatment, and year $\times$ treatment $(Y \times T)$ interaction effects, with the 1983 year's data as a covariate. Legume biomass (\%) is the same as for Lespedeza in Figure 1. ns, not significant: $P \geq 0.05$; ${ }^{\star} P<0.05$; ${ }^{* \star} P<0.01 ;{ }^{* \star} P<0.001$. Lower-case letters denote $P<0.05$. See Table 2 for corresponding $\mathrm{F}$ values.

dance of the invader, Kentucky bluegrass, but there were no other concomitant changes in vegetation composition, even after $20 \mathrm{yr}$ of applying fire at different frequencies. Fire also significantly increases bush clover in the sward, but only after $20 \mathrm{yr}$ of different fire treatments. The increased legume abundance with fire over time might lead to increased nitrogen inputs that may lead to vegetation changes in the long term. Therefore, frequent fire can decrease the abundance of Kentucky bluegrass, and increase the establishment of bush clover in this infertile prairie. However, management strategies aimed at increasing grassland diversity that try to lower Poa abundance by frequent burning may risk depleting plant species richness, at least in infertile grasslands. Any vegetation changes in unfertile grasslands induced by fire will likely take decades or centuries to develop.

\section{ACKNOWLEDGMENTS}

We thank Troy Mielke and the Cedar Creek interns for our field assistants. We also thank RaeAnn Power and Trevor Johnson for helping with fieldwork, Cathleen McFadden and Ilonka Zlatar for comments, and two anonymous reviewers for helpful criticism.

\section{LITERATURE CITED}

Amatangelo, K. L., J. S. Dukes, and C. B. Field. 2008. Responses of a California annual grassland to litter manipulation. Journal of Vegetation Science 19:605-612.

Ansley R. J., T. W. Boutton, M. Mirik, M. J. Castellano, and B. A. Kramp. 2010. Restoration of $\mathrm{C}_{4}$ grasses with seasonal fires in a $\mathrm{C}_{3} / \mathrm{C}_{4}$ grassland invaded by Prosopis glandulosa, a fire-resistant shrub. Applied Vegetation Science 13:520530. 
Briggs, J. M., A. K. Knapp, And B. L. Brock. 2002. Expansion of woody plants in tallgrass prairie: a 15-year study of fire and fire-grazing interactions. American Midland Naturalist 147:287-294.

Collins, S. L., And E. M. Steinauer. 1998. Disturbance, diversity, and species interactions in tallgrass prairie. In: A. K. Knapp, J. M. Briggs, D. C. Hartnett, and S. L. Collins [EDS.]. Grassland dynamics: long-term ecological research in tallgrass prairie. Oxford, UK: Oxford University Press. p. 193-221.

Gartner, F. R., J. R. Lindsey, and E. M. White. 1986. Vegetation responses to spring burning in western South Dakota. In: G. K. Clambey and R. H. Pemble [EDS.]. The prairie: past, present, and future. Proceedings of the Ninth North American Prairie Conference; 29 July-1 August 1986; Moorhead, MN, USA. Fargo, ND, USA: TriCollege University Centre for Environmental Studies, North Dakota State University. p. 143-146.

Grace, J. B., T. M. Anderson, M. D. Smith, E. Seabloom, S. J. Andelman, G. Meche, E. Weiher, L. K. Allain, H. Jutlla, M. Sankaran, J. Knops, M. Ritchie, and M. R. Willig. 2007. Does species diversity limit productivity in natural grassland communities? Ecology Letters 10:680-689.

Hartnett, D. C., K. R. Hickman, and L. E. Fisher Walter. 1996. Effects of bison grazing, fire and topography on floristic diversity in tallgrass prairie. Journal of Range Management 49:413-420.

Hendrickson, J. R., And C. Lund. 2010. Plant communities and target species affect responses to restoration strategies. Rangeland Ecology \& Management 63:435442.

HowE, H. F. 1995. Succession and fire season in experimental prairie plantings. Ecology 76:1917-1925.

Inouye, R. S., N. J. Huntly, D. Tilman, J. R. Tester, M. Stillwell, and K. C. Zinnel. 1987. Old-field succession on a Minnesota sand plain. Ecology 68:12-26.

Kauffman J. B., D. L. Cummings, and D. E. Ward. 1994. Relationships of fire, biomass and nutrient dynamics along a vegetation gradient in the Brazilian cerrado. Journal of Ecology 82:519-531.

KNops, J. M. H. 2006. Fire does not alter vegetation in infertile prairie. Oecologia 150:477-483.

Knops, J. M. H., M. G. Ritchie, And D. TILman. 2000. The effect of selective herbivory on a nitrogen fixing legume (Lathyrus venosus) on productivity and ecosystem nitrogen pools of an oak savanna. Ecoscience 7:166-174.

Knops, J. M. H., AND D. TILMAN. 2000. Dynamics of soil carbon and nitrogen accumulation for 61 years after agricultural abandonment. Ecology 81:88-98.

Lau, J. A., J. Strengbom, L. R. Stone, P. B. Reich, and P. Tiffin. 2008. Direct and indirect effects of $\mathrm{CO}_{2}$, nitrogen, and community diversity on plant-enemy interactions. Ecology 89:226-236

LI, W. J., J. H. LI, J. F. Lu, R.Y. Zhang, and G. Wang. 2010. Legume-grass species influence plant productivity and soil nitrogen during grassland succession in the eastern Tibet Plateau. Applied Soil Ecology 44:164-169.

Magurran, A. E. 1988. Ecological diversity and its measurement. Princeton, NJ, USA: Princeton University Press. $179 \mathrm{p}$.

Mlles, E. K., AND J. M. H. Knops. 2009a. Grassland compositional change in relation to the identity of the dominant matrix-forming grasses. Plant Ecology and Diversity $2: 265-275$.
Miles, E. K., and J. M. H. Knops. 2009b. Shifting dominance from native $\mathrm{C}_{4}$ to nonnative $\mathrm{C}_{3}$ grasses: relationships to community diversity. Oikos 118:1844-1853.

Morgan, J. W., and I. D. Lunt. 1999. Effects of time-since-fire on the tussock dynamics of a dominant grass (Themeda triandra) in a temperate Australian grassland. Biological Conservation 88:379-386.

Murphy, R. K., AND T. A. Grant. 2005. Land management history and floristics in mixed-grass prairie, North Dakota, USA. Natural Areas Journal 25:351-358.

Peterson, D. W., and P. B. Reich. 2008. Fire frequency and tree canopy structure influence plant species diversity in a forest-grassland ecotone. Plant Ecology 194:5-16.

Prober, S. M, K. R. Thiele, And I. D. Lunt. 2007. Fire frequency regulates tussock grass composition, structure and resilience in endangered temperate woodlands. Austral Ecology 32:808-824.

PYKE, D. A., M. L. BRooks, AND C. D. Antonio. 2010. Fire as a restoration tool: a decision framework for predicting the control or enhancement of plants using fire. Restoration Ecology 18:274-284.

Reed, H. E., T. R. Seastedt, and J. M. Blair. 2005. Ecological consequences of $\mathrm{C}_{4}$ grass invasion of $\mathrm{a}_{4}$ grassland: a dilemma for management. Ecological Applications 15:1560-1569.

Reich, P. B., D. W. Peterson, D. A. Wedin, and K. Wrage. 2001. Fire and vegetation effects on productivity and nitrogen cycling across a forest-grassland continuum. Ecology 82:1703-1719.

ReIchman, O. J. 1987. Konza Prairie: a tallgrass prairie natural history. Lawrence, KS, USA: University Press of Kansas. $226 p$.

Ritchie, M. E., AND D. TILman. 1995. Responses of legumes to herbivores and nutrients during succession on a nitrogen-poor soil. Ecology 76:2648-2655.

Schacht, W., and J. Stubbendeck. 1985. Prescribed burning in the loess hills mixed prairie of southern Nebraska. Journal of Range Management 38:47-51.

TLLmAN, D. 1984. Plant dominance along an experimental nutrient gradient. Ecology 65:1445-1453.

TILMAN, D. 1987. Secondary successional and the pattern of plant dominance along experimental nitrogen gradients. Ecological Monographs 57:189-214.

TiLman, D. 1997. Community invasibility, recruitment limitation and grassland biodiversity. Ecology 78:81-92.

Towne, E. G., AND K. E. Kemp. 2003. Vegetation dynamics from annually burning tallgrass prairie in different seasons. Journal of Range Management 56:185-192.

Towne, E. G., And A. K. Knapp. 1996. Biomass and density responses in tallgrass prairie legumes to annual fire and topographic position. American Journal of Botany 83:175-179.

Travnicek, A. J., R. G. Lym, and C. Prosser. 2005. Fall-prescribed burn and spring applied herbicide effects on Canada thistle control and soil seedbank in a northern mixed-grass prairie. Rangeland Ecology \& Management 58:413-422.

Uys, R. G., W. J. Bond, AND T. M. Everson. 2004. The effect of different fire regimes on plant diversity in southern African grasslands. Biological Conservation 118:489499.

Willson, G. D., And J. Stubbendeck. 1997. Fire effects on four growth stages of smooth brome (Bromus inermis, Leyess.). Natural Areas Journal 17:306-312. 